\title{
Percepton of Medical Students on Influence of Language Barrier in Bedside Teaching
}

\author{
Amulya $S,{ }^{1}$ Vidya $C ~ S,{ }^{2}$ Smitha $\mathrm{M} \mathrm{C}^{3}$ \\ 'II Year MBBS student \\ ${ }^{2}$ Professor of Anatomy \\ ${ }^{3}$ Assistant Professor of Community Medicine, JSS Medical College JSS AHER Mysore
}

Disclose and conflicts of interest: none to be declared by all authors

\begin{abstract}
Introduction: language provides an insight into the patients' suffering which is required to portray their illness or health condition. In Karnataka, Kannada is the local language and Medical students are expected to understand the local language during clinical postings and bedside teaching. Hence investigation on the influence of the language barrier should be critically reported for safety and quality health care.

Objective: to assess the perception of medical students on the influence of language barriers in bedside teaching-learning. Results: the responses were obtained from $52.7 \%$ of students in the second year, $23.6 \%$ in the third year, and $23.6 \%$ in the final years. Among the participants, $41.8 \%$ had south Indian languages like Malayalam, Telugu, Tamil, corgi as their native language and $58.2 \%$ had north Indian language as their native language. Out of them, $11.5 \%$ knew to communicate comfortably in the local language and $88.5 \%$ did not know how to speak the local language.

Conclusion: there was significant evidence suggesting that the language barrier affects the participants learning in clinical postings. An integration of clinical and communication skills in the regional language would enhance the learning of the medical students.
\end{abstract}

Keywords: Language barrier; Medical students; bedside teaching.

\section{Introduction}

Language being a tool is key to communication and helps humans to express emotions/feelings, convey opinions, share thoughts and ideas. Language provides an insight into the patients' suffering which is required to portray their illness or health condition. With the growth of evidence-based medicine, medical decisionmaking is expected to become more rational. ${ }^{1}$ Good communication and clinical skills together help in clinical reasoning and to arrive at a better diagnosis in the healthcare system. ${ }^{2}$

Language barriers have a considerable impact on the cost and quality of healthcare. They usually occur between healthcare workers and patients/informants when either of them is unable to comprehend the language effectively. ${ }^{3}$

Language barriers tend to make the delivery of high-quality healthcare very challenging. They can decrease the quality of healthcare, patient safety, and the medical professionals' and patients' satisfaction with the provided service. Language barriers may also lead to miscommunication between the medical professional and the patient. Medical professionals often perceive language barriers to be a source of workplace stress. ${ }^{4}$ Previous studies show a significant association between workplace stress and lower satisfaction among medical professionals. ${ }^{5}$

The linguistic gap can impact the students' confidence and change their way of taking a medical history. Moreover, a previous Egyptian study shows that two-thirds of students felt a gap between their education and clinical practice that might be due to their education in a non-native language. ${ }^{6}$

The use of professional medical interpreters could decrease health disparities for patients with limited knowledge of the local language, and also decrease medical mistakes, and thus provide greater patient satisfaction compared to the use of family members or bilingual staff.

There is a need to investigate and examine the methods and resources required to implement interventions in addition to identifying the most feasible and effective approach to deal with language barriers. ${ }^{8}$

Medical students in Karnataka encounter clinical scenarios in their lectures and small group discussions in English during their training. Whereas, the majority of the patients that the students have to deal with in 
hospital practice in Karnataka are native Kannada speaking or other language speakers. Misinterpretation of patient complaints or presentations is very common in a multilingual country like India. Language barriers need to be eliminated, especially in this ever-increasing global community where healthcare plays a major role. The purpose of this study is to investigate the impact of language barriers on the healthcare system and to suggest solutions to address the challenges faced by the patients as well as healthcare providers. Thus, we aimed to assess the perception of medical students on the influence of language barriers in a bedside teaching-learning environment.

\section{Material and Methods}

This cross-sectional study was conducted in JSS Medical College \& Hospital, JSS AHER, Mysore. Institution ethical committee clearance was obtained before the commencement of the study (JSSMC/ IEC/150521/03NCT/2021-2022 Dated 22/05/2021). The Academy has a 5-year medical curriculum with two pre-clinical years and two clinical years and one year of internship. The participants included the second, third, fourth- and fifth-year medical students. Students whose native language was Kannada were excluded from the study. 165 undergraduates (54.5\%females, $45.5 \%$ males) from whom voluntary consent was obtained, filled out a validated selfadministered questionnaire on the language barrier, delivered via google forms (Table 1). The students were approached through WhatsApp to fill the form and ensured that complete confidentiality would be maintained.

Table 1. Questionnaire on language barrier

\begin{tabular}{|c|c|}
\hline Q1 & $\begin{array}{l}\text { I feel the language barrier influences my learning in clinical } \\
\text { posting }\end{array}$ \\
\hline Q2 & $\begin{array}{l}\text { Language barrier makes it harder to communicate with } \\
\text { patients from rural background }\end{array}$ \\
\hline Q3 & $\begin{array}{l}\text { Language barrier makes it harder to communicate with } \\
\text { patients from urban background }\end{array}$ \\
\hline Q4 & $\begin{array}{l}\text { Language barrier has made communication with patients } \\
\text { difficult while taking history }\end{array}$ \\
\hline Q5 & $\begin{array}{l}\text { Language barrier has made retaining information more } \\
\text { difficult }\end{array}$ \\
\hline Q6 & $\begin{array}{l}\text { Language barrier has made adapting to clinical postings } \\
\text { more difficult }\end{array}$ \\
\hline Q7 & $\begin{array}{l}\text { Language barrier has made bedside teaching learning less } \\
\text { enjoyable }\end{array}$ \\
\hline Q8 & $\begin{array}{l}\text { Language barrier affects my participation in bedside } \\
\text { teaching-learning }\end{array}$ \\
\hline Q9 & Language barrier affects my academic performance \\
\hline Q10 & $\begin{array}{l}\text { I need help from my peers to take patient history during } \\
\text { clinical postings due to language barrier }\end{array}$ \\
\hline Q11 & $\begin{array}{l}\text { I support exclusive classes in the local language in first year } \\
\text { of MBBS }\end{array}$ \\
\hline
\end{tabular}

We assessed the association between students' responses to the different items of the questionnaire.

Data analysis was done using MS Excel and SPSS software. Descriptive statistics like mean, median, standard deviation, Interquartile range, and proportions were used and Inferential statistics like Chi-square analysis/ Fischer exact test was used to find the association between the perception of language barrier and gender, year of study, native language, etc. Graphical representation was used whenever it was required.

\section{Results}

There were 165 responses, $45.5 \%$ were males and $54.5 \%$ were females. Students from the second year were $52.7 \%$, while $23.6 \%$ were in the third year and $23.6 \%$ were in the final years. Among the participants, $41.8 \%$ spoke south Indian languages like Malayalam, Telugu, Tamil, and Corgi as their native language and 58.2\% had north Indian language as their native language. Out of them, $11.5 \%$ knew to communicate comfortably in the local language and $88.5 \%$ did not speak the local language. Figure 1 shows the percentage of answers for each question individually.

Concerning the native language, there was a significant association seen between perception affecting participants learning in clinical postings about responses to questions, if they feel the language barrier influencing their learning in clinical posting $(\mathrm{p}=0.023)$, if language barrier had made communication with patients difficult while taking history $(p=0.011)$, if language barrier made bedside teaching/learning less enjoyable $(\mathrm{p}=0.003)$, and if they would need help from their peers to take the patient's history during clinical postings due to language barrier $(\mathrm{p}<0.001)$. For the participants' ability to communicate in the local language there was a significant association to responses about questions, if language barrier makes it harder to communicate with patients from a rural background $(\mathrm{p}<0.001)$, if language barrier made communication with patients difficult while taking history $(\mathrm{p}=0.07)$, if language barrier had made adopting to clinical postings more difficult $(p=0.007)$, if language barrier would affect their participation in bedside teaching/learning $(p=0.002)$ and if they needed help from their peers to take patient history during clinical postings due to language barrier $(\mathrm{p}<0.001)$ (Table 2).

While there was no association seen between gender and the participant's perception of the influence of language barrier on clinical postings, concerning the year of study, there was a significant association in response to questions, if language barrier makes it harder to communicate with patients from an urban background $(\mathrm{p}=0.005)$ and if language barrier has made bedside teaching/learning less enjoyable $(p=0.015)$ (Table 3). 
Table 2. Association of perception of influence of language barrier on learning during clinical postings with respect to their mother tongue and their ability to communicate in local language

\begin{tabular}{|c|c|c|c|c|c|c|c|c|c|}
\hline \multirow{2}{*}{ Questions } & \multirow{2}{*}{ Responses } & \multicolumn{2}{|c|}{$\begin{array}{l}\text { Know to communicate } \\
\text { in local language }\end{array}$} & \multirow{2}{*}{$\begin{array}{l}\text { Chi-square } \\
\text { value/ } \\
\text { Fischer } \\
\text { exact value }\end{array}$} & \multirow{2}{*}{ p-value } & \multicolumn{2}{|c|}{ Mother tongue } & \multirow{2}{*}{$\begin{array}{l}\text { Chi-square } \\
\text { value/ } \\
\text { Fischer } \\
\text { exact value }\end{array}$} & \multirow{2}{*}{ p-value } \\
\hline & & No & Yes & & & $\begin{array}{l}\text { South } \\
\text { Indian }\end{array}$ & $\begin{array}{l}\text { North } \\
\text { Indian }\end{array}$ & & \\
\hline \multirow{3}{*}{$\begin{array}{l}\text { I feel the language barrier } \\
\text { influences my learning in } \\
\text { clinical posting }\end{array}$} & Agree & $\begin{array}{c}138- \\
83.63 \%\end{array}$ & $17-10.30 \%$ & \multirow{3}{*}{2.36} & \multirow{3}{*}{0.323} & 95 & 60 & \multirow{3}{*}{6.717} & \multirow{3}{*}{$0.023 *$} \\
\hline & Don't know & $6-3.63 \%$ & $1-0.60 \%$ & & & 1 & 6 & & \\
\hline & Disagree & $2-1.21 \%$ & $1-0.60 \%$ & & & 1 & 2 & & \\
\hline \multirow{3}{*}{$\begin{array}{l}\text { Language barrier makes } \\
\text { it harder to communicate } \\
\text { with patients from rural } \\
\text { background }\end{array}$} & Agree & $144-87.27 \%$ & $17-10.30 \%$ & \multirow{3}{*}{8.71} & \multirow{3}{*}{$<0.001^{\star}$} & 96 & 65 & \multirow{3}{*}{2.809} & \multirow{3}{*}{$0.309 *$} \\
\hline & Don't know & $2-1.21 \%$ & 0 & & & 1 & 1 & & \\
\hline & Disagree & 0 & $\begin{array}{c}2- \\
1.21 \%\end{array}$ & & & 0 & 2 & & \\
\hline \multirow{3}{*}{$\begin{array}{l}\text { Language barrier makes } \\
\text { it harder to communicate } \\
\text { with patients from urban } \\
\text { background }\end{array}$} & Agree & $72-43.63 \%$ & $11-6.66 \%$ & \multirow{3}{*}{0.611} & \multirow{3}{*}{0.737} & 54 & 29 & \multirow{3}{*}{3.616} & \multirow{3}{*}{$0.164^{*}$} \\
\hline & Don't know & $42-25.45 \%$ & $4-2.42 \%$ & & & 22 & 24 & & \\
\hline & Disagree & $32-19.39 \%$ & $4-2.42 \%$ & & & 21 & 15 & & \\
\hline \multirow{3}{*}{$\begin{array}{l}\text { Language barrier has } \\
\text { made communication with } \\
\text { patients difficult while } \\
\text { taking history }\end{array}$} & Agree & $\begin{array}{c}140- \\
84.84 \%\end{array}$ & $16-9.69 \%$ & \multirow{3}{*}{5.1} & \multirow{3}{*}{$0.07^{*}$} & 95 & 61 & \multirow{3}{*}{7.3} & \\
\hline & Don't know & $3-1.81 \%$ & $2-1.21 \%$ & & & 0 & 5 & & $0.011^{*}$ \\
\hline & Disagree & $3-1.81 \%$ & $1-0.60 \%$ & & & 2 & 2 & & \\
\hline Language barrier & Agree & $\begin{array}{c}100- \\
60.60 \%\end{array}$ & $12-7.27 \%$ & & & 68 & 44 & & \\
\hline $\begin{array}{l}\text { has made retaining } \\
\text { information more difficult }\end{array}$ & Don't know & $27-16.36 \%$ & $4-2.42 \%$ & 0.505 & 0.007 & 15 & 16 & 1.76 & 0.413 \\
\hline & Disagree & $19-11.51 \%$ & $3-1.81 \%$ & & & 14 & 8 & & \\
\hline & Agree & $119-72.12 \%$ & $10-6.06 \%$ & & & 80 & 49 & & \\
\hline made adapting to clinical & Don't know & $14-8.48 \%$ & $3-1.81 \%$ & 8.81 & $0.007^{*}$ & 9 & 8 & 2.9 & 0.226 \\
\hline postings more alticutt & Disagree & $13-7.87 \%$ & $6-3.63 \%$ & & & 9 & 11 & & \\
\hline lanouaøo harrier hac & Agree & $92-55.75 \%$ & $8-4.84 \%$ & & & 68 & 32 & & \\
\hline made bedside teaching & Don't know & $20-12.12 \%$ & $2-1.21 \%$ & 4.64 & $0.091^{*}$ & 13 & 9 & 11.7 & 0.003 \\
\hline teaming tess enjoyadie & Disagree & $34-20.60 \%$ & $9-17.94 \%$ & & & 16 & 27 & & \\
\hline 1 an & Agree & $115-69.69 \%$ & $8-4 . .84 \%$ & & & 76 & 47 & & \\
\hline my participation in & Don't know & $9-5.45 \%$ & $4-2.42 \%$ & 11.4 & $0.002^{*}$ & 5 & 8 & 2.8 & 0.243 \\
\hline Dedside teaching & Disagree & $22-13.33 \%$ & $7-4.24 \%$ & & & 16 & 13 & & \\
\hline & Agree & 65 & $7-4.24 \%$ & & & 46 & 26 & & \\
\hline $\begin{array}{l}\text { Language barrier affects } \\
\text { my academic performance }\end{array}$ & Don't know & $36-39.39 \%$ & $4-2.42 \%$ & 0.98 & 0.612 & 20 & 20 & 2.05 & 0.359 \\
\hline & Disagree & $45-27.27 \%$ & $8-4.84 \%$ & & & 31 & 22 & & \\
\hline I need help from my peers & Agree & $\begin{array}{c}139- \\
84.24 \%\end{array}$ & $13-7.87 \%$ & & $0001 *$ & 96 & 56 & & \\
\hline during clinical postings & Don't know & $1-0.60 \%$ & $1-0.60 \%$ & 12.9 & $0.001 \times$ & 0 & 2 & 14.78 & $<0.001^{*}$ \\
\hline & Disagree & $6-3.63 \%$ & $5-3.03 \%$ & & & 1 & 10 & & \\
\hline & Agree & $127-76.96 \%$ & $14-8.48 \%$ & & & 85 & 56 & & \\
\hline in the local language in & Don't know & $12-7.27 \%$ & $2-1.21 \%$ & 3.8 & 0.149 & 6 & 8 & 1.6 & 0.449 \\
\hline tirst year of I & Disagree & $7-4.24 \%$ & $3-1.81 \%$ & & & 6 & 4 & & \\
\hline
\end{tabular}

*Fischer Exact Test 


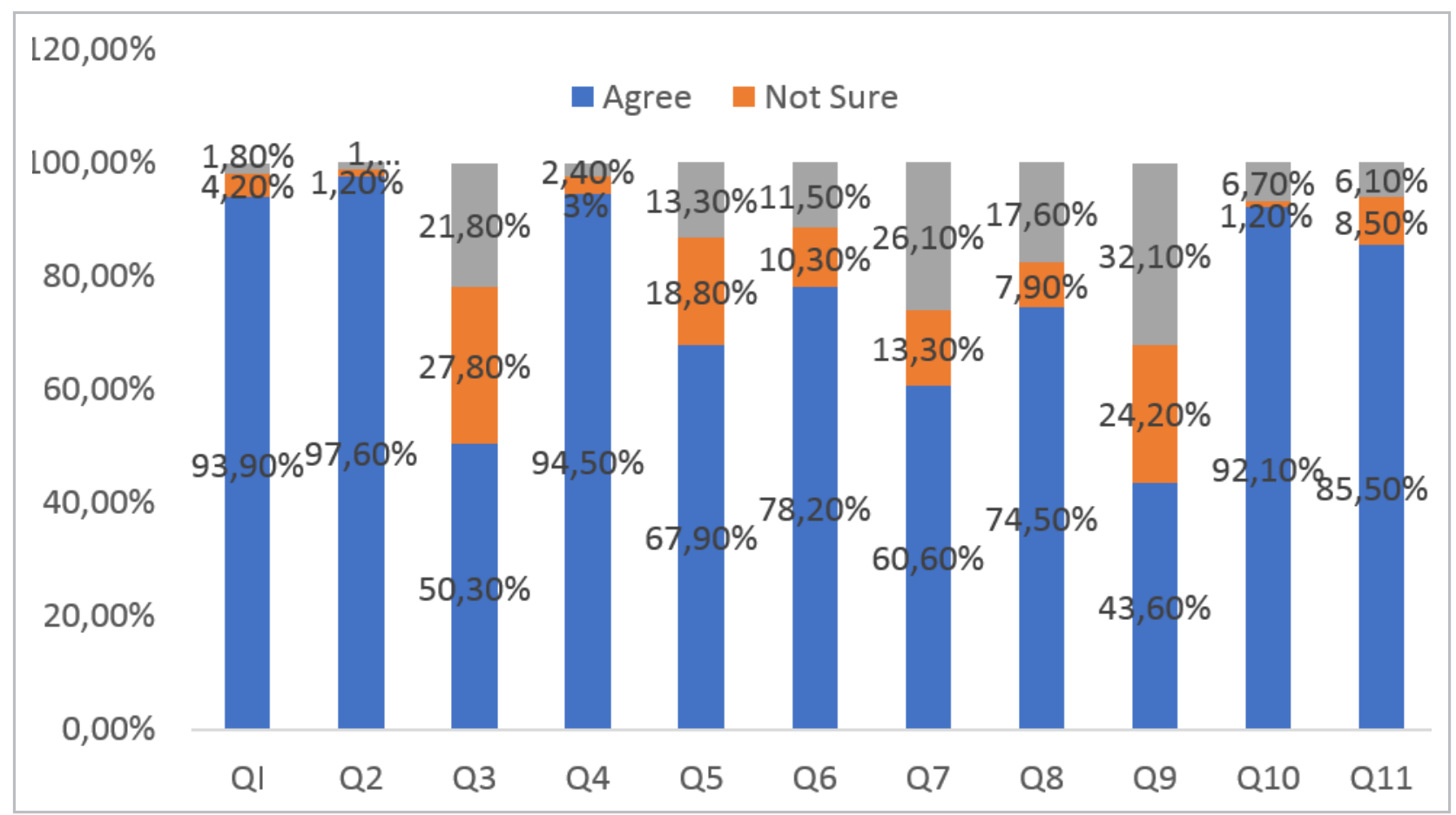

Figure 1. Representation of responses from study participants

Table 3. Association of perception of influence of language barrier on learning during clinical postings with respect to gender and year of study

\begin{tabular}{|c|c|c|c|c|c|c|c|c|c|c|}
\hline \multirow{2}{*}{ Questions } & \multirow{2}{*}{ Responses } & \multicolumn{2}{|c|}{ Gender } & \multirow{2}{*}{$\begin{array}{l}\text { Chi-square } \\
\text { value/ } \\
\text { Fischer } \\
\text { exact value }\end{array}$} & \multirow{2}{*}{ p-value } & \multicolumn{3}{|c|}{ Year of study } & \multirow{2}{*}{$\begin{array}{l}\text { Chi-square } \\
\text { value/ } \\
\text { Fischer } \\
\text { exact value }\end{array}$} & \multirow{2}{*}{ p-value } \\
\hline & & Female & Male & & & $\begin{array}{c}\text { Second } \\
\text { Year }\end{array}$ & $\begin{array}{l}\text { Third } \\
\text { Year }\end{array}$ & $\begin{array}{l}\text { Final } \\
\text { Year }\end{array}$ & & \\
\hline \multirow{3}{*}{$\begin{array}{l}\text { I feel the language } \\
\text { barrier influences my } \\
\text { learning in clinical } \\
\text { posting }\end{array}$} & Agree & $85-51.51 \%$ & $70-42.42$ & \multirow{3}{*}{0.711} & \multirow{3}{*}{$0.752^{*}$} & 86 & 38 & 37 & \multirow{3}{*}{0.973} & \multirow{3}{*}{$0.951^{*}$} \\
\hline & Don't know & $4-2.42 \%$ & $3-1.81 \%$ & & & 5 & 2 & 2 & & \\
\hline & Disagree & $1-0.60 \%$ & $2-1.21 \%$ & & & 6 & 4 & 4 & & \\
\hline \multirow{3}{*}{$\begin{array}{l}\text { Language barrier } \\
\text { makes it harder to } \\
\text { communicate with } \\
\text { patients from rural } \\
\text { background }\end{array}$} & Agree & $88-53.33 \%$ & $73-44.24 \%$ & \multirow{3}{*}{3.3} & \multirow{3}{*}{$0.165^{*}$} & 88 & 41 & 42 & \multirow{3}{*}{4.24} & \multirow{3}{*}{$0.343^{*}$} \\
\hline & Don't know & $2-1.21 \%$ & 0 & & & 4 & 0 & 1 & & \\
\hline & Disagree & 0 & $2-1.21 \%$ & & & 5 & 3 & 0 & & \\
\hline \multirow{3}{*}{$\begin{array}{l}\text { Language barrier } \\
\text { makes it harder to } \\
\text { communicate with } \\
\text { patients from urban } \\
\text { background }\end{array}$} & Agree & $44-26.66 \%$ & $39-23.63 \%$ & \multirow{3}{*}{1.73} & \multirow{3}{*}{0.421} & 34 & 26 & 28 & \multirow{3}{*}{14.6} & \multirow{3}{*}{0.005} \\
\hline & Don't know & $23-13.93 \%$ & $23-13.93 \%$ & & & 32 & 9 & 10 & & \\
\hline & Disagree & $23-13.93 \%$ & $13-7.87 \%$ & & & 31 & 9 & 5 & & \\
\hline \multirow{3}{*}{$\begin{array}{l}\text { Language barrier has } \\
\text { made communication } \\
\text { with patients difficult } \\
\text { while taking history }\end{array}$} & Agree & $85-51.51 \%$ & $71-43.03 \%$ & \multirow{3}{*}{0.299} & \multirow{3}{*}{$1.000^{*}$} & 84 & 41 & 39 & \multirow{3}{*}{3.0} & \multirow{3}{*}{0.578} \\
\hline & Don't know & $3-1.81 \%$ & $2-1.21 \%$ & & & 6 & 0 & 2 & & \\
\hline & Disagree & $2-1.21 \%$ & $2-1.21 \%$ & & & 7 & 3 & 2 & & \\
\hline \multirow{3}{*}{$\begin{array}{l}\text { Language barrier } \\
\text { has made retaining } \\
\text { information more } \\
\text { difficult }\end{array}$} & Agree & $58-35.15 \%$ & $54-32.72 \%$ & \multirow{3}{*}{1.99} & \multirow{3}{*}{0.369} & 56 & 29 & 34 & \multirow{3}{*}{7.89} & \multirow{3}{*}{0.096} \\
\hline & Don't know & $17-10.30$ & $14-8.48 \%$ & & & 19 & 10 & 5 & & \\
\hline & Disagree & $15-9.09 \%$ & $7-4.24 \%$ & & & 22 & 5 & 4 & & \\
\hline \multirow{3}{*}{$\begin{array}{l}\text { Language barrier } \\
\text { has made adopting } \\
\text { to clinical postings } \\
\text { more difficult }\end{array}$} & Agree & $68-41.21 \%$ & $61-36.96 \%$ & & & 66 & 32 & 38 & & \\
\hline & Don't know & $12-7.27 \%$ & $5-3.03 \%$ & 1.96 & 0.374 & 13 & 5 & 2 & 6.43 & 0.169 \\
\hline & Disagree & $10-6.06 \%$ & $9-5.45 \%$ & & & 18 & 7 & 3 & & \\
\hline
\end{tabular}




\begin{tabular}{|c|c|c|c|c|c|c|c|c|c|c|}
\hline \multirow{3}{*}{$\begin{array}{l}\text { Language barrier } \\
\text { has made bedside } \\
\text { teaching learning } \\
\text { less enjoyable }\end{array}$} & Agree & $51-30.90 \%$ & $49-29.69 \%$ & \multirow{3}{*}{1.46} & \multirow{3}{*}{0.481} & 45 & 26 & 33 & \multirow{3}{*}{12.3} & \multirow{3}{*}{0.015} \\
\hline & Don't know & $14-8.48 \%$ & $8-4.84 \%$ & & & 18 & 4 & 3 & & \\
\hline & Disagree & $25-15.15 \%$ & $18-10.90 \%$ & & & 34 & 14 & 7 & & \\
\hline \multirow{3}{*}{$\begin{array}{l}\text { Language barrier } \\
\text { affects my } \\
\text { participation in } \\
\text { bedside teaching- } \\
\text { learning }\end{array}$} & Agree & $69-41.81 \%$ & $54-32.72 \%$ & \multirow{3}{*}{1.48} & \multirow{3}{*}{0.477} & 62 & 33 & 35 & \multirow{3}{*}{5.79} & \multirow{3}{*}{0.215} \\
\hline & Don't know & $5-3.03 \%$ & $8-4.84 \%$ & & & 11 & 3 & 1 & & \\
\hline & Disagree & $16-9.69 \%$ & $13-7.87 \%$ & & & 24 & 8 & 7 & & \\
\hline \multirow{3}{*}{$\begin{array}{l}\text { Language barrier } \\
\text { affects my academic } \\
\text { performance }\end{array}$} & Agree & $44-26.66 \%$ & $28-16.96 \%$ & \multirow{3}{*}{2.78} & \multirow{3}{*}{0.248} & 31 & 20 & 24 & \multirow{3}{*}{8.21} & \multirow{3}{*}{0.084} \\
\hline & Don't know & $18-10.90$ & $22-13.33 \%$ & & & 28 & 8 & 7 & & \\
\hline & Disagree & $28-16.96 \%$ & $25-15.15$ & & & 38 & 16 & 12 & & \\
\hline \multirow{3}{*}{$\begin{array}{l}\text { I need help from my } \\
\text { peers to take patient } \\
\text { history during clinical } \\
\text { postings due to } \\
\text { language barrier }\end{array}$} & Agree & $82-49.69 \%$ & $70-42.42 \%$ & \multirow{3}{*}{0.645} & \multirow{3}{*}{$0.878^{*}$} & 79 & 41 & 38 & \multirow{3}{*}{4.64} & \multirow{3}{*}{$0.267^{*}$} \\
\hline & Don't know & $1-0.60 \%$ & $1-0.60 \%$ & & & 5 & 0 & 0 & & \\
\hline & Disagree & $7-4.24 \%$ & $4-2.42 \%$ & & & 13 & 3 & 5 & & \\
\hline \multirow{3}{*}{$\begin{array}{l}\text { I support exclusive } \\
\text { classes in the local } \\
\text { language in first year } \\
\text { of MBBS }\end{array}$} & Agree & $76-46.06 \%$ & $65-39.39 \%$ & \multirow{3}{*}{1.1} & \multirow{3}{*}{0.576} & 81 & 37 & 34 & \multirow{3}{*}{1.09} & \multirow{3}{*}{$0.916^{*}$} \\
\hline & Don't know & $7-4.24 \%$ & $7-4.24 \%$ & & & 9 & 3 & 5 & & \\
\hline & Disagree & $7-4.24 \%$ & $3-1.81 \%$ & & & 7 & 4 & 4 & & \\
\hline
\end{tabular}

*Fischer Exact Test

\section{Discussion}

In medical educational institutions, when the language for communication with the patient is different from the language the student can comprehend, the language barrier may affect the students learning and professional life. This study aimed to look into the differences created due to the language barrier among medical students and how it affected their learning and understanding during clinical postings as well as their academic performance. In addition, it aimed at understanding the students' perception of the need for a regional language training program in medical school. The present study shows that $94.54 \%$ of students agree that the language barrier has made communication with patients difficult while taking a medical history. Previously, an Indian study by Krishnan $\mathrm{P}$ showed that students studying in English had a tough time taking the medical history of the patients in medical school. ${ }^{9}$ Moreover, an Arabic study conducted among final year medical students reports that $72 \%$ of the students felt confident in taking medical history in Arabic and 66\% felt easier to communicate with the patients in Arabic. ${ }^{10}$ However, another study, shows that students were less confident in taking patient history in their local language than in English. ${ }^{5}$ In another Arabic study, 72.2\% of students said they felt confident in taking a medical history in English, while 27.8\% of students expressed confidence in taking medical history in Arabic ${ }^{11}$.

In this study, $78.18 \%$ of students felt that the language barrier has made adapting to clinical postings more difficult and $74.53 \%$ of students agreed that it affects their participation in bedside teaching/learning. A previous study reports that $70.6 \%$ of students preferred to study history taking in their native language $\mathrm{e}^{12}$. Another study shows that $47.6 \%$ of students preferred training for Objective Structured Clinical Examination (OSCE) in their native language rather than English and $68 \%$ of students suggested adding short regional language history courses while $20 \%$ disagreed about preferring to be trained for OSCE in the regional language ${ }^{5}$. Another study reported that for descriptive knowledge, students preferred discussion in their native language $\mathrm{p}<0.005^{13}$. A Malaysian study shows that students trained in Australia found it difficult to communicate with patients in their native language ${ }^{14}$.

In the present study, $78.18 \%$ of students felt that the language barrier has made adapting to clinical postings more difficult $(\mathrm{p}=0.007)$, following a similar study, that showed a higher but still significant $p$-value $(p=0.038)^{9}$.

A South African study showed that the current medical education doesn't support the needs of the local community in terms of communication with the students ${ }^{15}$. Also, a Saudi study showed Arabic-English code-switching during teaching was found to be an effective way for course content comprehensibility ${ }^{16}$.

One limitation of this study is a relatively small sample size (165 students). The students could reflect their own perception rather than their actual performance in the clinical practice, and this problem could be addressed by assessing them through a test. Also, this study was conducted in a single institution, thus the issue must be explored in government colleges and other private institutions for better understanding the results. 


\section{Conclusion}

There was significant evidence suggesting that the language barrier affects the participants learning in clinical postings. An integration of clinical practice with communication skills in the regional language would enhance the learning of the medical students. Symptoms and certain medical terminologies could be taught in both Kannada and English.

Hence this study may help promptly to discuss the feasibility of teaching local language exclusively from the first year onwards to overcome the problem.

\section{Recommendations}

While 141 students support exclusive Kannada classes during the first year of MBBS, many students also thought that learning the basics of the regional language is a must-know to communicate with patients and that Kannada classes should be conducted once a week throughout their study years.

\section{References}

1.Franz B, Murphy J. Reconsidering the role of language in medicine. Philosophy, Ethics, and Humanities in Medicine. 2018;13(1).

2. Kurtz S, Silverman J, Benson J, Draper J. Marrying content and process in clinical method teaching: Enhancing the CalgaryCambridge guides. Acad Med. 2003;78(8):802-809.

3. Sam Slade, Shane R. Sergent. Language Barrier . PubMed. 2021 [cited 14 July 2021.

4. Hilal Al Shamsi, Abdullah G. Almutairi, Sulaiman Al Mashrafi, and Talib Al Kalbani. Implications of Language Barriers for Healthcare: A Systematic Review 2020;30:e122 .

5. Elena Fiabane, Ines Giorgi, D Musian, Cinzia Sguazzin, P Argentero. Occupational stress and job satisfaction of healthcare staff in rehabilitation units. 2012; 103(6):482-92.

6. Muhannad A Alnahdi, et al. The impact of the English medical curriculum on medical history taking from Arabic speaking patients by medical students. $2021 ; 10(3)$ : 1425-1430.

7. Jason Espinoza, and Sabrina Derrington. How Should Clinicians Respond to Language Barriers That Exacerbate Health Inequity?. AMA Journal of Ethics. 2021;23(2):E109-116.

8.Truong M, Paradies Y, Priest N. Interventions to improve cultural competency in healthcare: a systematic review of reviews. BMC Health Services Research. 2014;14(1).

9. Krishnan P. Medical education. Health Millions 1992;18:42 4.
10. Tayem Y, AlShammari A, Albalawi N, Shareef M. Language barriers to studying medicine in English: perceptions of final-year medical students at the Arabian Gulf University. Eastern Mediterranean Health Journal. 2020;26(2):233-238.

11. Sabbour S, Dewedar S, Kandil S. Language barriers in medical education and attitudes towards Arabization of medicine: student and staff perspectives. Eastern Mediterranean Health Journal. 2010;16(12):1263-1271.

12. Al Turki M, Mohamud M, Masuadi E, Altowejri M, Farraj A, Schmidt $\mathrm{H}$. The Effect of Using Native versus Nonnative Language on the Participation Level of Medical Students during PBL Tutorials. Health Professions Education. 2020;6(4):447-453.

13. Chur-Hansen A. Returning home to work: Malaysian students who studied medicine overseas. Med Teach 2004;26:343-8.

14. Matthews MG, Van Wyk JM. Exploring a communication curriculum through a focus on social accountability: A case study at a South African medical school. Afr J Prim Health Care Fam Med 2018;10:1634 15. Mirza DM, Hashim MJ. Communication skills training in English alone can leave Arab medical students unconfident with patient communication in their native language. Educ Health 2010;23:450. 16. Alenezi MQ, Kebble PG. Investigating Saudi Medical Students' Attitudes Towards English-Arabic Code-Switching in Classroom Instruction. The Asian ESP Journal. 2018 14(1):142-160.
Received: June 1, 2021

Accepted: August 25, 2021
Corresponding author

Vidya C S

E-mail:vidyacs@jssuni.edu.in 